\title{
Phylogenetic diversity and functional gene patterns of sulfur-oxidizing subseafloor Epsilonproteobacteria in diffuse hydrothermal vent fluids
}

\author{
Nancy H. Akerman ${ }^{1+}$, David A. Butterfield ${ }^{2}$ and Julie A. Huber ${ }^{1 *}$ \\ 1 Josephine Bay Paul Center for Comparative Molecular Biology and Evolution, Marine Biological Laboratory, Woods Hole, MA, USA \\ 2 Joint Institute for the Study of the Atmosphere and Ocean, University of Washington and NOAA Pacific Marine Environmental Lab, Seattle, WA, USA
}

Edited by:

Andreas Teske, University of North

Carolina at Chapel Hill, USA

Reviewed by:

Casey R. J. Hubert, Newcastle

University, UK

Gordon Webster, Cardiff University, UK

\section{${ }^{*}$ Correspondence:}

Julie A. Huber, Josephine Bay Paul

Center for Comparative Molecular Biology and Evolution, Marine

Biological Laboratory, 7 MBL Street. Woods Hole, MA 02543, USA

e-mail: jhuber@mbl.edu

${ }^{\dagger}$ Present address:

Nancy H. Akerman, US

Environmental Protection Agency,

Washington, DC USA
Microorganisms throughout the dark ocean use reduced sulfur compounds for chemolithoautotrophy. In many deep-sea hydrothermal vents, sulfide oxidation is quantitatively the most important chemical energy source for microbial metabolism both at and beneath the seafloor. In this study, the presence and activity of vent endemic Epsilonproteobacteria was examined in six low-temperature diffuse vents over a range of geochemical gradients from Axial Seamount, a deep-sea volcano in the Northeast Pacific. PCR primers were developed and applied to target the sulfur oxidation soxB gene of Epsilonproteobacteria. soxB genes belonging to the genera Sulfurimonas and Sulfurovum are both present and expressed at most diffuse vent sites, but not in background seawater. Although Sulfurovum-like soxB genes were detected in all fluid samples, the RNA profiles were nearly identical among the vents and suggest that Sulfurimonas-like species are the primary Epsilonproteobacteria responsible for actively oxidizing sulfur via the Sox pathway at each vent. Community patterns of subseafloor Epsilonproteobacteria 16S rRNA genes were best matched to methane concentrations in vent fluids, as well as individual vent locations, indicating that both geochemistry and geographical isolation play a role in structuring subseafloor microbial populations. The data show that in the subseafloor at Axial Seamount, Epsilonproteobacteria are expressing the soxB gene and that microbial patterns in community distribution are linked to both vent location and chemistry.

Keywords: sulfur oxidation, hydrothermal vent microbiology, 16S rRNA, functional genes, subseafloor, Epsilonproteobacteria

\section{INTRODUCTION}

Sulfur is an abundant, multi-valent element in deep-sea hydrothermal vent systems. Large metal sulfide chimneys and biofilms containing filamentous sulfur are often present, and hydrogen sulfide concentrations are typically in the millimolar range (Sievert et al., 2008a). The high concentrations of hydrogen sulfide $\left(\mathrm{H}_{2} \mathrm{~S}\right)$ at deep-sea vents are produced mainly via high-temperature seawater-rock interactions in the subseafloor hydrothermal reaction zone (Jannasch and Mottl, 1985). Other partially reduced sulfur compounds, such as thiosulfate, polysulfide, and elemental sulfur, are generated when hydrothermal vent fluids mix with oxygenated seawater (Yamamoto and Takai, 2011). At deep-sea hydrothermal vent systems, the microbiallymediated oxidation of reduced sulfur compounds is a key chemolithotrophic process that provides a substantial primary energy source for higher organisms (Jannasch and Mottl, 1985; Sievert et al., 2008a). Thermodynamic modeling studies show that sulfide oxidation is the major energy source at most nonperidotite, basalt-hosted deep-sea hydrothermal vent systems (Amend et al., 2011), including Axial Seamount on the Juan de Fuca Ridge (Butterfield et al., 2004). Microbial sulfate reduction also occurs across a range of temperatures in hydrothermal discharge areas (Bonch-Osmolovskaya et al., 2011). Even away from hydrothermal vents, it is clear that reduced inorganic sulfur compounds play an important role in chemolithoautotrophic metabolism throughout the dark ocean (Walsh et al., 2009; Orcutt et al., 2011; Swan et al., 2011).

Many bacteria and some archaea have the capability of oxidizing sulfur or sulfide to sulfate. In bacteria, there are two different sulfur oxidation pathways: the reverse sulfate reduction pathway, which uses the Dsr, Apr, or Sat enzymes (Kappler and Dahl, 2001), and the sulfur oxidation Sox multienzyme system (Friedrich et al., 2001, 2005). The Sox system contains four protein components, SoxYZ, SoxXA, SoxB, and SoxCD, for the complete oxidation of sulfide and thiosulfate to sulfate (Friedrich et al., 2005). The SoxB protein, encoded by the $\operatorname{soxB}$ single copy gene, has been identified as the sulfate thiol esterase in the Sox system, and the $\operatorname{sox} B$ gene is used as a marker gene to survey sulfur oxidizing bacteria (Friedrich et al., 2005). Homologous proteins to SoxB have not been found in the domain Archaea (Friedrich et al., 2001). Polymerase chain reaction (PCR) primers targeting the $\operatorname{sox} B$ gene have previously been developed; these sets are based on Chlorobia and Alphaproteobacteria sequences and were refined using additional Alphaproteobacteria and Aquificales sequences (Petri et al., 2001). The primers have been extensively tested and found to amplify the $\operatorname{sox} B$ gene from mostly 
photo- and chemotrophic sulfur oxidizing species, including the Gammaproteobacteria (Meyer et al., 2007), with additional examples from the Epsilonproteobacteria (Hügler et al., 2010). However, some of the primer sets developed by Petri et al. (2001) are degenerate primers that result in multiple PCR amplicons of approximately the same size, which can give ambiguous sequencing results, and some key phylogenetic groups may also be missed when applied to diverse habitats (Petri et al., 2001; Meyer et al., 2007; Headd and Engel, 2013).

The purpose of this study was to design and test soxB PCR primers specific to the Epsilonproteobacteria to evaluate the presence, diversity, and gene expression of sulfur-oxidizing Epsilonproteobacteria at deep-sea hydrothermal vent systems. Chemolithoautotrophic Epsilonproteobacteria are often the most abundant group of bacteria detected in both the free-living and symbiotic microbial communities at deep-sea vents (e.g., Huber et al., 2003; Nakagawa et al., 2007; Nakagawa and Takai, 2008; Sievert et al., 2008a). Epsilonproteobacterial isolates from vents include Sulfurimonas autotrophica DSM16294, Sulfurovum sp. NBC37-1, and Nitratiruptor sp. SB155-2. All recently had their genomes sequenced (Nakagawa et al., 2007; Sikorski et al., 2010), along with a closely related coastal wetland isolate $S$. denitrificans DSM1251 (Sievert et al., 2008b), and all have the capability of oxidizing reduced sulfur compounds using the sulfur oxidation Sox multienzyme system (Yamamoto and Takai, 2011). This new genomic information was used to develop and test $\operatorname{sox} B$ gene PCR primers specific to the Epsilonproteobacteria at diffuse vents from Axial Seamount, where Epsilonproteobacteria are known to dominate many low-temperature vent fluids (Huber et al., 2003; Sogin et al., 2006; Huber et al., 2007; Opatkiewicz et al., 2009). After primer optimization and testing, six lowtemperature diffuse hydrothermal vent samples that span a range of temperature, $\mathrm{pH}$, sulfide, and geological settings were screened using both $16 \mathrm{~S}$ rRNA 454 pyrosequencing and the new soxB gene primers to evaluate the presence, diversity, and gene expression of sulfur-oxidizing Epsilonproteobacteria at deep-sea hydrothermal vent systems.

\section{EXPERIMENTAL PROCEDURES SAMPLE SITE}

Axial Seamount $\left(46^{\circ} 55^{\prime} \mathrm{N} ; 130^{\circ} 00^{\prime} \mathrm{W}\right)$ is an active underwater volcano located approximately 250 nautical miles west of the Oregon/Washington coast at the intersection of the Juan de Fuca Ridge and the Cobb-Eickelberg Seamount Chain. The caldera of Axial Seamount is oriented northwest-to-southeast and is $3 \times 8 \mathrm{~km}$, with hydrothermal vent fields associated with the north and south rift zones and near the caldera boundary fault in the southern half of the caldera (Embley et al., 1990; Butterfield et al., 2004). All samples in this study were collected from hydrothermal sites along the southern caldera boundary fault.

\section{SAMPLE COLLECTION}

Hydrothermal fluid samples were collected in August and September 2010 using the ROV Jason II and the Hydrothermal Fluid and Particulate Sampler (HFPS) (Butterfield et al., 2004). The titanium intake nozzle with in-line temperature probe was inserted into the vents, with the tip generally penetrating into the seafloor. Filtered and unfiltered fluids were sampled after a steady in-line temperature was found and the sampling pump was then turned on to collect fluids at the rate of $\sim 150 \mathrm{ml} / \mathrm{min}$. Temperature was monitored and recorded throughout sampling and the maximum and average temperatures for the samples are reported (Table 1). Three liters of fluid was filtered onto

Table 1 | Characteristics of vent fluid and seawater samples.

\begin{tabular}{|c|c|c|c|c|c|c|c|}
\hline & Gollum & Marker 33 & Marker 113 & Pompeii & Escargot & $9 \mathrm{~m}$ & Seawater \\
\hline Vent type & Basalt & Basalt & Basalt & Sulfide & Sulfide & Sulfide & \\
\hline Cells/ml & $5.1 \times 10^{5}$ & $6.3 \times 10^{4}$ & $6.7 \times 10^{5}$ & $4.8 \times 10^{5}$ & $3.8 \times 10^{5}$ & $3.6 \times 10^{5}$ & $1.8 \times 10^{4}$ \\
\hline $\mathrm{T}_{\max },{ }^{\circ} \mathrm{C}$ & 22.3 & 39.0 & 29.1 & 33.8 & 22.7 & 51.3 & 2 \\
\hline $\mathrm{T}_{\text {avg }},{ }^{\circ} \mathrm{C}$ & 21.4 & 38.3 & 27.9 & 31.1 & 20.6 & 49.7 & 2 \\
\hline $\mathrm{pH}$ & 5.7 & 5.5 & 6.0 & 5.4 & 5.0 & 4.8 & 7.8 \\
\hline Avg Alk, Meq/kg & 2.77 & 1.62 & 2.46 & 2.21 & 2.32 & 2.03 & 2.43 \\
\hline Avg Si, $\mu \mathrm{mol} / \mathrm{kg}$ & 815 & 2857 & 326 & 1568 & 1575 & 2169 & 155 \\
\hline $\mathrm{Mg}, \mathrm{mmol} / \mathrm{kg}$ & 50.7 & 41.8 & 50.4 & 46.7 & 48.1 & 44.4 & 52.9 \\
\hline$\%$ Seawater $^{a}$ & 96 & 79 & 95 & 88 & 91 & 84 & 100 \\
\hline $\mathrm{H}_{2} \mathrm{~S}, \mu \mathrm{M}$ & 84 & 929 & 748 & 452 & 554 & 1626 & 0 \\
\hline $\mathrm{NH}_{3}, \mu \mathrm{M}$ & 5.19 & 6.05 & 4.68 & 3.74 & 4.95 & 10.64 & $<0.6$ \\
\hline $\mathrm{H}_{2} \mathrm{~S} / \mathrm{Heat}^{\mathrm{b}}$ & 1 & 6.3 & 6.9 & 4 & 6.6 & 8.6 & 0 \\
\hline $\mathrm{H}_{2} /$ Heat $^{\mathrm{b}}$ & 0.00 & 0.12 & 0.00 & 0.17 & 0.10 & 0.29 & 0 \\
\hline $\mathrm{CH}_{4} / \mathrm{Heat}^{\mathrm{b}}$ & 0.09 & 0.13 & 0.38 & 0.05 & 0.11 & 0.06 & 0 \\
\hline $\mathrm{Fe} / \mathrm{Heat}^{\mathrm{b}}$ & 0.01 & 0.02 & 0.01 & 0.03 & 0.07 & 0.36 & 0 \\
\hline $\mathrm{Fe} / \mathrm{Mn}$ & 0.03 & 0.03 & 1.52 & 0.17 & 0.35 & 1.36 & 0 \\
\hline $\mathrm{Mn} / \mathrm{Heat}^{\mathrm{b}}$ & 0.21 & 0.59 & 0.01 & 0.18 & 0.21 & 0.26 & 0 \\
\hline
\end{tabular}

a \% Seawater calculated as $M g_{v f} / M g_{s w} \times 100$. Subscripts: vf, vent fluid; sw, seawater.

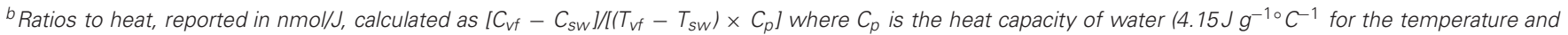
pressure in this study). 
Sterivex filters (Millipore) or 47-mm flat filters (Millipore) for DNA analysis and RNA analysis, respectively. For the $47 \mathrm{~mm}$ filters, a McLane "pancake" style filter assembly was used and filled with RNALater (Life Technologies), so that immediately after filtration, RNALater diffused over the filter surface and remained until ROV recovery (Cowen et al., 2012). A background seawater sample outside of the Axial Seamount caldera was collected via CTD at $\sim 1500 \mathrm{~m}$ depth, and $\sim 3 \mathrm{~L}$ of seawater was filtered onto a flat filter on board the ship. Sterivex filters were flooded with RNALater, sealed with Male/Female Luer Caps, and stored in 50-mL sterile Falcon tubes, while flat filters were stored in 5-mL sterile plastic tubes filled with RNALater. All filters were stored at $4^{\circ} \mathrm{C}$ for $24 \mathrm{~h}$ before being stored at $-80^{\circ} \mathrm{C}$ until nucleic acid extraction in the laboratory. Fluid samples for chemistry were analyzed shipboard for $\mathrm{pH}$, alkalinity, hydrogen sulfide, ammonia, methane and hydrogen following the methods of Butterfield et al. (2004). Major cations and anions were analyzed by ion chromatography and iron and manganese were analyzed by atomic absorption and/or ICP-MS on shore. Fluid samples were preserved in formaldehyde for cell enumeration using epifluorescence microscopy with DAPI as described previously (Huber et al., 2002).

\section{DNA EXTRACTION}

Genomic DNA was extracted from Sterivex filters following the procedure outlined in Sogin et al. (2006) and Huber et al. (2002), with the following minor modifications. RNALater was removed from the filter via pushing the liquid out with a $3 \mathrm{ml}$ syringe. $1.85 \mathrm{~mL}$ of DNA extraction buffer $(0.1 \mathrm{M}$ Tris- $\mathrm{HCl}$ [pH 8], $0.1 \mathrm{M}$ $\mathrm{Na}_{2}$-EDTA [pH 8], $0.1 \mathrm{M} \mathrm{NaH}_{2} \mathrm{PO}_{4}$ [pH 8], 1.5 M NaCl, and 1\% cetyltrimethlammonium bromide) was then added to the filter. Sterivex filters were then re-capped and the extraction method of Huber et al. (2002) with modifications in Sogin et al. (2006) followed. Successful DNA extraction was verified via PCR using bacterial $16 \mathrm{~S}$ primers $8 \mathrm{~F}\left(5^{\prime}\right.$-AGA GTT TGA TCC TGG CTC AG-3') and 1492R (5'-GGT TAC CTT GTT ACG ACT T-3') and visualized under UV light on a $1 \%$ agarose gel stained with ethidium bromide.

\section{RNA EXTRACTION AND REVERSE TRANSCRIPTION PCR}

RNA filters were allowed to thaw at room temperature in their 5-mL storage tubes. Total RNA was extracted using the RNAqueous-4PCR kit (Ambion), with the following adaptations. First, RNALater was discarded from the 5-mL tube, and $500 \mu \mathrm{l}$ of lysis/binding solution was added directly to the tube. Tubes were vortexed at high speed for $\sim 2 \mathrm{~min}$. The lysis/binding solution was removed from the tube and placed in a $2-\mathrm{mL}$ collection tube. An additional $500 \mu \mathrm{l}$ of lysis/binding solution was added to the 5-mL tube, and the vortex and collection steps were repeated. The protocol was then followed per manufacturer's instructions, including the DNase 1 treatment step. The final elution volume was $120 \mu \mathrm{l}$. RNA was quantified using the Quant-iT RiboGreen RNA Reagent and Kit (Invitrogen) and a Turner Biosystems Spectrophotometer. Approximately $30 \mathrm{ng}$ of total RNA was reverse transcribed using the High Capacity RNA-to-cDNA Kit (Applied Biosystems) according to the manufacturer's instructions.

\section{SOXB GENE PRIMER DESIGN AND PCR OPTIMIZATION USING SULFURIMONAS DENITRIFICANS}

Primers were designed using multiple alignments of soxB genes from Epsilonproteobacterial species Nitratiruptor sp. SB155-2, Sulfurovum sp. NBC-37, and Sulfurimonas denitrificans DSM 1225 (Table 2). Initial primer sequences were created using the soxB nucleotide sequences in Primaclade (Gadberry et al., 2005) and PriFi (Fredslund et al., 2005), and the amino acid sequences in iCODEHOP (Boyce et al., 2009). Sequences were then manually adjusted based on the initial bacterial sequences. CODEHOPs are hybrid primers that consist of a $5^{\prime}$ nondegenerate clamp, followed by a $3^{\prime}$ degenerate core sequence (indicated in lowercase nucleotides) that stabilizes hybridization (Rose, 2003). Primers were manufactured by Invitrogen (Carlsbad, CA).

\section{Sulfurimonas denitrificans}

DSM 1251 was obtained from the DSMZ culture collection and grown using DSMZ Medium 113, with an additional 10 $\mathrm{g} / \mathrm{L} \mathrm{NaCl}$ and substituting trace element solution 141 (from DSMZ Medium 141) for trace element solution SL-4. DNA was extracted from S. denitrificans using the UltraClean Microbial DNA Isolation Kit (MoBio Laboratories, Inc.), using $3 \mathrm{~mL}$ of culture and an initial extended centrifugation time ( $8 \mathrm{~min})$.

Optimal annealing conditions for the primers were determined via gradient PCR using $S$. denitrificans DNA as template. Primers were tested in the following pairs (Table 2): sox190F/sox1198R, sox527F/sox1198R, sox523F/sox1210R, sox $523 \mathrm{~F} /$ sox $1292 \mathrm{R}$, and sox $523 \mathrm{~F} / \mathrm{F}-34 \mathrm{R}$. Gradients were $42-51^{\circ} \mathrm{C}$ for sox $190 \mathrm{~F} / \mathrm{sox} 1198 \mathrm{R}$, and $52-60^{\circ} \mathrm{C}$ for all other primer sets. Annealing temperatures of $45^{\circ} \mathrm{C}$ for sox190F/sox $1198 \mathrm{R}, 46^{\circ} \mathrm{C}$ for sox $527 \mathrm{~F} / \operatorname{sox} 1198 \mathrm{R}$, and $52^{\circ} \mathrm{C}$ for sox $523 \mathrm{~F} / \operatorname{sox} 1210 \mathrm{R}$ and sox $523 \mathrm{~F} / \mathrm{sox} 1292 \mathrm{R}$ were chosen based on visual inspection of the gradient PCR results on a $1 \%$ agarose gel stained with ethidium bromide and photographed under UV light. The

Table 2 | soxB primers designed and PCR settings used in this study.

\begin{tabular}{|c|c|c|}
\hline Primer & Sequence & $\begin{array}{l}\text { Target } \\
\text { nucleotide } \\
\text { position }^{a}\end{array}$ \\
\hline sox190F & 5'-TGGAGRGAGCCWTCAAC-3' & 190-206 \\
\hline sox527F & 5'-TGGTWGGWCAYTGGGAATTTA-3' & $527-547$ \\
\hline sox523F & 5'-GTGATGGTTGGACAytgggartwya-3' & $523-547$ \\
\hline sox1198R & 5'-AGAANGTATCTCKYTTATAAAG-3' & 1198-1177 \\
\hline sox1210R & 5'-CGAAGGTGGAGTAGAAngtrtctckytt-3' & $1210-1183$ \\
\hline sox1292R & 5'-GTCGTTCCCCATckrtanccngg-3' & $1292-1270$ \\
\hline F-34R & 5'-CTCAAAGGTGTAAACGtynggatakgt-3' & \\
\hline $\begin{array}{l}\text { Primer } \\
\text { combinations }\end{array}$ & $\begin{array}{l}\text { Annealing } \\
\text { temperature }\left({ }^{\circ} \mathrm{C}\right)\end{array}$ & $\begin{array}{l}\text { Amplicon } \\
\text { length (bp) }\end{array}$ \\
\hline sox190F/sox1198R & 45 & 1009 \\
\hline sox527F/sox1198R & 46 & 672 \\
\hline sox523F/sox1210R & 52 & 688 \\
\hline sox523F/sox1292R & 52 & 770 \\
\hline
\end{tabular}

${ }^{a}$ Using S. denitrificans numbering. 
PCR reaction mixture consisted of $1 \mathrm{X}$ buffer (Promega), $4 \mathrm{mM}$ $\mathrm{MgCl}_{2}, 0.2 \mathrm{mM}$ of each deoxynucleoside triphosphate (dNTP), $0.6 \mu \mathrm{M}$ of each primer, 1U GoTaq polymerase (Promega), $1 \mu \mathrm{L}$ DNA template, and DEPC $\mathrm{H}_{2} \mathrm{O}$ to $25 \mu \mathrm{L}$. Thermocycling conditions on an Eppendorf thermal cycler consisted of an initial denaturation step at $94^{\circ} \mathrm{C}$ for $3 \mathrm{~min}$, followed by 35 cycles at $94^{\circ} \mathrm{C}$ for $30 \mathrm{~s}$, applicable annealing temperature for $45 \mathrm{~s}$, and $72^{\circ} \mathrm{C}$ for $1 \mathrm{~min}$, followed by a final extension at $72^{\circ} \mathrm{C}$ for $5 \mathrm{~min}$. Using these PCR conditions, all primer sets yielded a single band amplicon of the predicted size, which ranged from $\sim 670$ to $1000 \mathrm{bp}$ depending on the primer set. PCR products were verified to be the correct size on a $1 \%$ agarose gel stained with ethidium bromide and photographed under UV light. PCR products were cleaned using the MinElute PCR Purification Kit (Qiagen) following the manufacturer's instructions and directly sequenced on an Applied Biosystems 3730XL sequencer. DNA sequences were compared to sequences in the NCBI database via BLAST and in all cases were the $\operatorname{soxB}$ gene of $S$. denitrificans DSM 1251.

\section{SOXB GENE CLONING, SEQUENCING, AND ANALYSIS}

Each of the 4 primer sets were used with appropriate PCR settings as outlined above on DNA and cDNA from all fluid samples. PCR was visualized by UV light on ethidium bromide-stained 1\% agarose gels. While multiple primer sets were tested on each sample, only amplicons from primer pair sox $527 \mathrm{~F} / 1198 \mathrm{R}$ were cloned and sequenced. For the background seawater sample, only primer pair sox 523F/1292R amplified, thus it was cloned and sequenced. PCR products were purified using the MinElute PCR Purification Kit (Qiagen) and the products analyzed on $0.8 \%$ agarose gel. Products were gel excised, purified, cloned, and sequenced bidirectionally as described in Huber et al. (2009). Primer sequences were trimmed from nucleotide sequences and translated into amino acids using EMBOSS Transeq (Rice et al., 2000). A protein distance matrix was calculated in ProtDist (Felsenstein, 1989) and operational taxonomic units (OTUs) constructed in mothur (Schloss et al., 2009). Phylogenetic relationships of representative $85 \%$ amino acid identity OTUs to other soxB genes were determined using MEGA5 (Tamura et al., 2007). Sequences are deposited in GenBank under the following Accession Numbers: KC793341-KC793868.

\section{PYROSEQUENCING AND ANALYSIS}

Amplicons targeting the V4V6 rRNA hypervariable region were generated for each DNA and cDNA sample following Filkins et al. (2012). A custom bioinformatic pipeline was used to remove low quality reads according to Filkins et al. (2012). The algorithm GAST assigned taxonomy to each unique read (Huse et al., 2008). All high quality reads that passed initial processing were further analyzed and trimmed to the V5 region based on high error rates at the V4 end, resulting in $\sim 350$ bp reads, and UCLUST (Edgar, 2010) identified operational taxonomic units (OTUs) with $96 \%$ sequence identity. Singletons were removed from all subsequent reported analyses. The resulting matrix of OTUs shared between samples was used to construct taxonomic summaries and compare background seawater and vent samples. The OTU matrices were normalized to total and transformed via square root and used to calculate a distance matrix with the Morisita-Horn measure (Horn, 1966). Distance matrices were imported into PRIMER-E (Clarke and Gorley, 2006) for a variety of analyses, including hierarchical cluster analysis, principal component analysis (PCO), analysis of similarity (ANOSIM), and nonmetric multidimensional scaling (MDS) analysis. The entire chemical dataset was also included for PCA and Spearman correlation analyses. To predict which OTUs were active or inactive, the top OTUs that occurred greater than $0.1 \%$ of the total sequences in either the RNA or DNA fraction for both the Epsilon- and Gammaproteobacteria were examined. Each OTU was scored as active or inactive based on its recovery in DNA and RNA samples (Jones and Lennon, 2010). Data is accessible via vamps.mbl.edu under project name JAH_AXV_Bv6v4.

\section{RESULTS}

\section{AXIAL SEAMOUNT FLUID SAMPLES}

Fluid samples were collected from basalt- or sulfide-hosted diffuse flow venting sites with varying physical and chemical parameters, as well as from background seawater (Table 1). Gollum, Marker 33, and Marker 113 sites discharge vent fluids directly from basalt, while Pompeii, Escargot, and $9 \mathrm{~m}$ sites discharge vent fluids from the sides of metal-sulfide chimneys. Fluids at Pompeii were emanating from a large clump of tubeworms. These samples span a range of sulfide to heat ratios (calculated using the measured $\mathrm{H}_{2} \mathrm{~S}$ concentration and the average in-line temperature of individual samples, Table 1), reflecting different concentrations of hydrogen sulfide in end-member hydrothermal fluids and variable sulfide oxidation (Butterfield et al., 2004). The site with the lowest sulfide/heat ratio of $1.0 \mathrm{nmol} / \mathrm{J}$ was Gollum, the midrange site Pompeii had a ratio of 4 , and the other four sample sites had ratios between 6 and 9. Average temperatures ranged from 20.6 to $49.7^{\circ} \mathrm{C}$. The measured temperatures and magnesium content of the collected samples indicate that the fluids are 79-96\% seawater (4-21\% hot hydrothermal end-member) overall, but this percentage does not tell us their mixing history or subseafloor residence time.

\section{SOXB GENE DATA}

Primers that specifically target the Epsilonproteobacteria soxB gene were designed by comparing conserved regions of the Sulfurimonas denitrificans DSM 1225, Sulfurovum sp. NBC37-1, and Nitratiruptor sp. SB155-2 soxB genes (Nakagawa et al., 2007; Sievert et al., 2008b). The primers are not capable of identifying Arcobacter-like sequences. The Arcobacter soxB sequences cluster in a different clade (Hügler et al., 2010), and homologous regions for primer annealing could not be identified across all Epsilonproteobacteria genera, while excluding other groups. The primers were tested and PCR settings were optimized using DNA extracted from a pure culture of $S$. denitrificans. Three forward and three reverse primers were used in four combinations (Table 2). The sequences were translated to amino acid residues and checked via BLASTP and alignment to verify amplification of the sox $B$ gene. The four different primer sets amplified sox $B$ gene fragments ranging in size from 672 to $1009 \mathrm{bp}$. The primer sets were additionally tested on environmental DNA samples and were shown to be capable of amplifying Sulfurovum-, Sulfurimonas-, and Nitratiruptor-like soxB sequences (Meyer et al., 2013). 
The four soxB primer sets were used to amplify soxB from the DNA and RNA fractions of the six Axial Seamount hydrothermal vent fluid samples and the background seawater sample. Positive amplicons were obtained from six of the seven DNA fractions, with the exception of Pompeii. In the RNA fractions, amplicons were not obtained from Pompeii, $9 \mathrm{~m}$, and the background seawater sample. A total of 480 clones were sequenced across the nine DNA and RNA vent fluid samples and the one DNA background seawater sample (Table 3 ).

All hydrothermal vent $\operatorname{sox} B$ clones were most closely related to the Sulfurimonas (Slms) and Sulfurovum (Sfvm) genera in the Epsilonproteobacteria and represented 10 different phylotypes at an $85 \%$ amino acid identity level (Figures 1, 2). Of the 405 clones from the nine hydrothermal libraries, all but 37 fell into 3 main OTUs. The most common OTU, Slms-1, represented $\sim 80 \%$ of all the clones and was detected at all positively amplified hydrothermal samples in both the DNA and RNA fractions. The other two most common clone sequences were Sulfurovumlike phylotypes Sfvm-A and Sfvm-B, which represented 6 and $4 \%$, respectively, of all hydrothermal clones. Sfvm-A was detected in the DNA fraction of all sites, but only in the RNA fraction at Gollum. Sfvm-B was only detected in the DNA fractions at Gollum and Marker 33 and in none of the RNA fractions (Figure 2).

Overall, only one Sulfurovum-like $\operatorname{soxB}$ gene was found in the RNA fraction (Gollum). Instead, Slms-1 was the only soxB gene detected in all of the RNA fractions (Figure 2) and was also the most abundant soxB gene in all DNA fractions, except for Gollum. At Gollum, the composition of the DNA and RNA libraries differed, with the DNA library dominated by Sulfurovum-like soxB gene sequences and the RNA fraction almost completely composed of Slms-1. No comparisons could be made between the

Table 3 | Sequencing statistics for 16S rRNA and soxB gene sequences.

\begin{tabular}{|c|c|c|c|c|c|}
\hline & $\begin{array}{l}\text { Nucleic } \\
\text { acid }\end{array}$ & $\begin{array}{l}\text { Total tag } \\
\text { sequences }^{a}\end{array}$ & $\begin{array}{l}\text { Total } \\
\text { epsilon tag } \\
\text { sequences }\end{array}$ & $\%$ Epsilons & $\begin{array}{l}\text { Total soxB } \\
\text { sequences }^{b}\end{array}$ \\
\hline \multirow[t]{2}{*}{ Gollum } & DNA & 14866 & 7000 & 47.1 & 47 \\
\hline & RNA & 11128 & 157 & 1.4 & 48 \\
\hline \multirow[t]{2}{*}{ Marker 33} & DNA & 15773 & 8117 & 51.5 & 45 \\
\hline & RNA & 11166 & 248 & 2.2 & 45 \\
\hline \multirow[t]{2}{*}{ Marker 113} & DNA & 14820 & 3998 & 27.0 & 38 \\
\hline & RNA & 14451 & 2870 & 19.9 & 46 \\
\hline \multirow[t]{2}{*}{ Pompeii } & DNA & 16538 & 6699 & 40.5 & - \\
\hline & RNA & 10475 & 694 & 6.6 & - \\
\hline \multirow[t]{2}{*}{ Escargot } & DNA & 15457 & 6174 & 39.9 & 46 \\
\hline & RNA & 98143 & 18453 & 18.8 & 46 \\
\hline \multirow[t]{2}{*}{$9 \mathrm{~m}$} & DNA & 17570 & 3241 & 18.4 & 44 \\
\hline & RNA & 10256 & 407 & 4.0 & - \\
\hline Seawater & DNA & 11682 & 0 & 0 & 75 \\
\hline Total & - & 262325 & 58058 & - & 480 \\
\hline
\end{tabular}

a No singletons.

b Primer set 527F/1198R was used for all vent samples; 523F/1292 for seawater.
DNA and RNA fractions of the $9 \mathrm{~m}$ site since $\operatorname{soxB}$ was not amplified from the RNA fraction.

In the background seawater sample, a total of five phylotypes were found, with the two most dominant OTUs representing $94 \%$ of the background clones. All phylotypes were most closely related to Alphaproteobacteria, although these BLASTP matches were made at approximately $67 \%$ identity rather than the 90-99\% identity of the Epsilonproteobacteria BLASTP hits in the libraries from the venting fluids (Figure 1). These Alphaprotoebacteria-like sequences were not found in the vent samples.

\section{$16 S$ rRNA GENE 454 PYROSEQUENCING}

454 pyrosequencing of the bacterial $16 \mathrm{~S}$ rRNA gene from both the DNA and cDNA from all samples resulted in 262,325 high-quality non-singleton tag sequences across the hydrothermal and background seawater sites (a DNA library only was constructed for the background seawater sample, Table 3). Epsilonproteobacteria (58,058 sequences) were present in all 12 hydrothermal vent fluid libraries (Table 3, Figure 3). Epsilonproteobacterial sequences were not detected in background seawater, even before singletons were removed (Table 3, Figure 3). The background seawater sample was mostly composed of Alpha- and Gammaproteobacteria (Figure 3). Within the Epsilonproteobacteria, sequences of the genera Sulfurimonas and Sulfurovum dominated most libraries (Figure 4), although at Pompeii, Escargot, and $9 \mathrm{~m}$, numerous Caminibacter sequences were also detected (Figure 4). The only other major group within the Epsilonproteobacteria was Arcobacter, which comprised almost 9\% of the DNA fraction at Marker 33. In all cases, Epsilonproteobacteria sequences were more abundant in DNA fractions than RNA fractions for each individual vent (Figure 4). Comparison of rRNA profiles of the most abundant OTUs for Epsilonproteobacteria shows most Epsilonproteobacteria were inactive in the sampled vent fluids. Out of 164 Epsilonproteobacteria OTUs considered, only 22 were scored as active (Table 4 ).

To distinguish vent-specific microbial communities from background seawater communities that mix with venting fluids at the seafloor, all $16 \mathrm{~S}$ rRNA gene OTUs as well as only Epsilonproteobacterial 16S rRNA gene OTUs were analyzed separately. SIMPROF tests of all OTU datasets indicated there is significant community structure among the individual samples $(\pi=6.48, P$ value $<0.001$ for all OTUs. $\pi=$ 8.46, $P$ value $<0.001$ for Epsilonprotoebacterial OTUs). OneWay ANOSIM (analysis of similarity) tests with a variety of factors resulted in significant global $\mathrm{R}$ values for individual vent sampled and type of vent (basalt or sulfide) for both all OTUs and only Epsilonprotebacterial OTUs; values were higher for Epsilonproteobacteria $(R=0.84, P$ value $<0.001$ for Epsilonproteobacteria and individual vent; $R=0.55, P$ value $=0.004$ for Epsilonproteobacteria and type of vent). The type of nucleic acid analyzed (RNA or DNA) was significant only when all OTUs were considered $(R=0.39, P$ value $=0.006)$. Principal coordinates analysis of all OTUs showed a clear distinction between DNA and RNA fractions (Figure 5) that was not seen when only Epsilonproteobacterial OTUs were analyzed in the same manner (Figure 6). BEST analysis [Biota and/or 


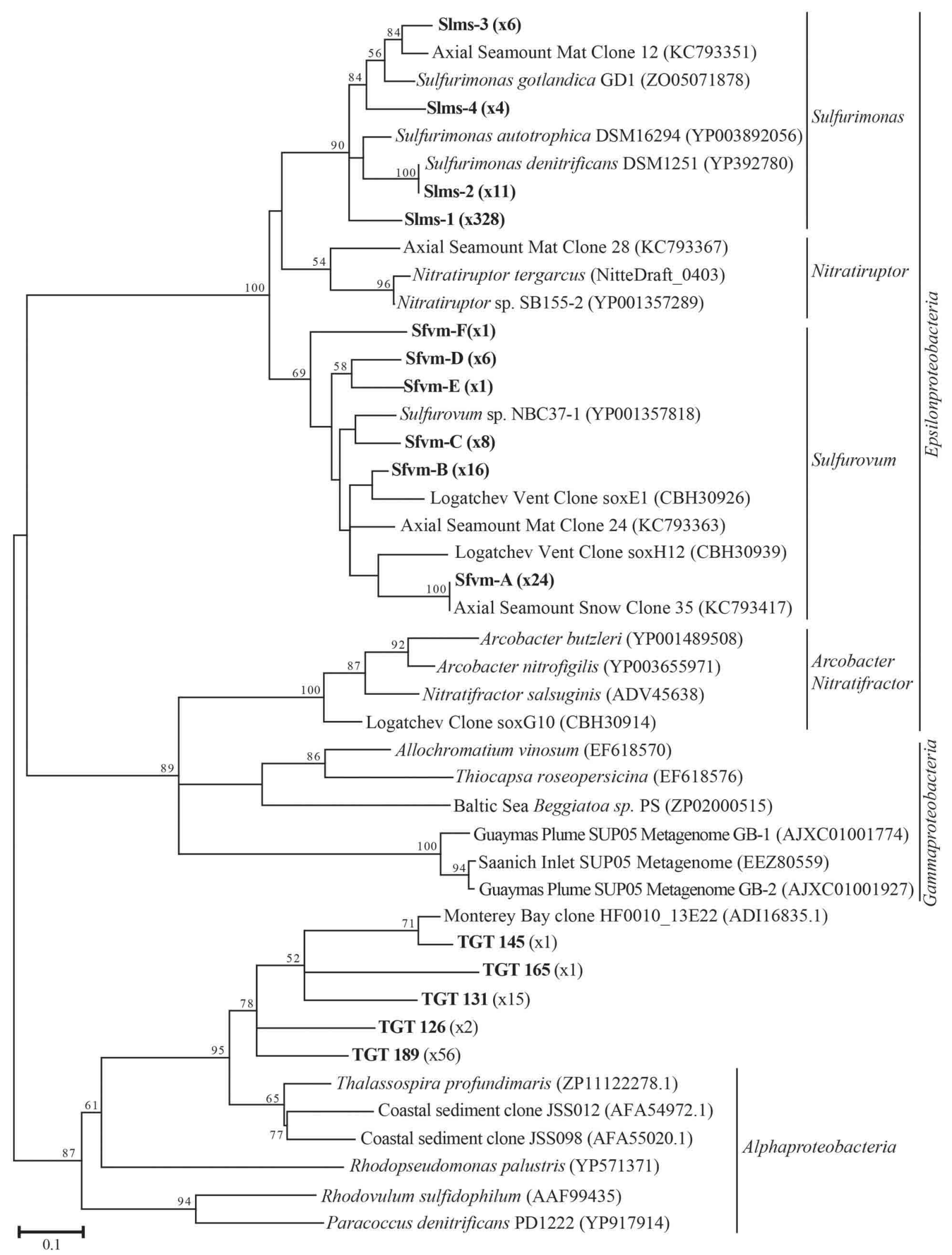

FIGURE 1 | Maximum likelihood phylogenetic tree showing the relationships of the $15 \%$ soxB gene OTUs found in this study (indicated in boldface) with number of sequences belonging to each
OTU indicated in parentheses. The maximum likelihood tree was calculated based on $\sim 234$ amino acid residues and bootstrap values above 50 are shown. 


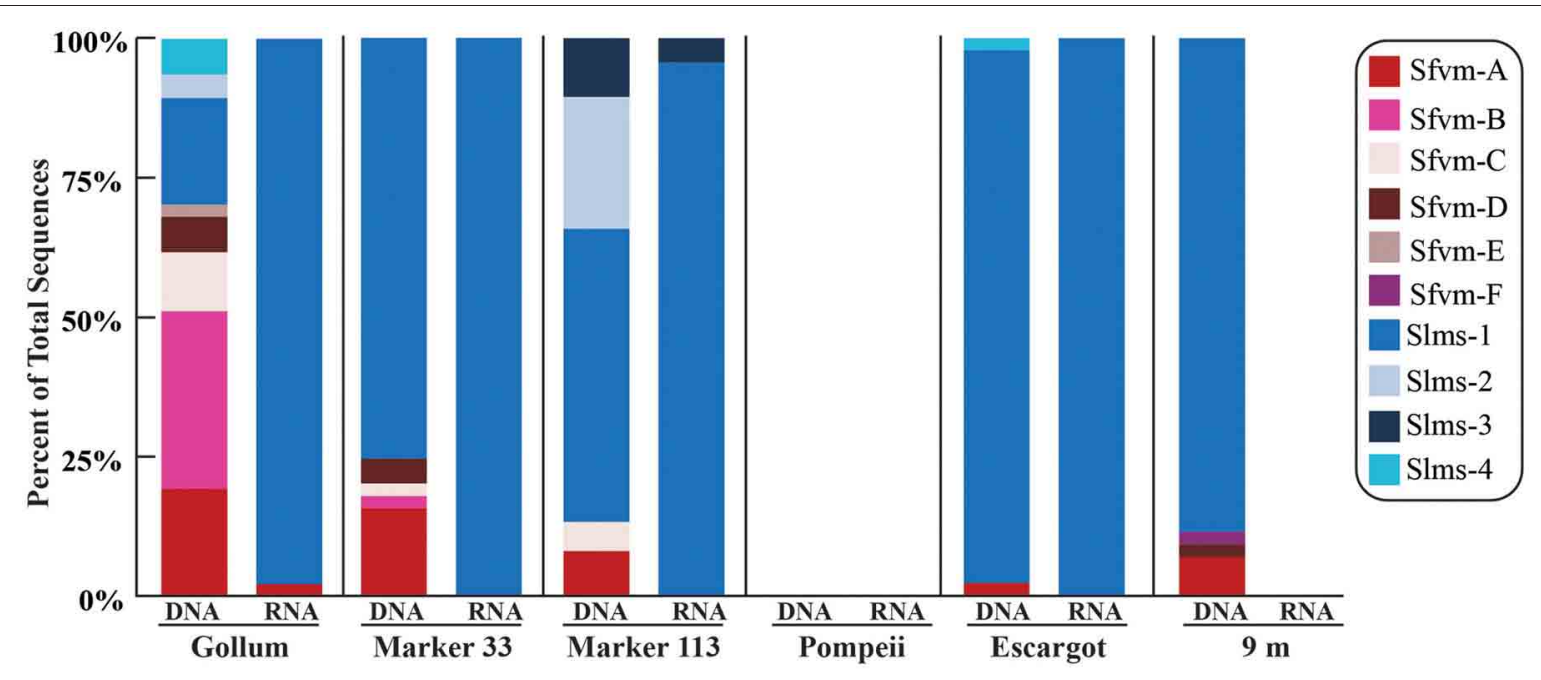

FIGURE 2 | Relative abundance with taxonomic affiliation of the $15 \%$ soxB gene OTUs in the DNA and RNA fractions of different vents classified according to the phylogenetic tree in Figure 1.

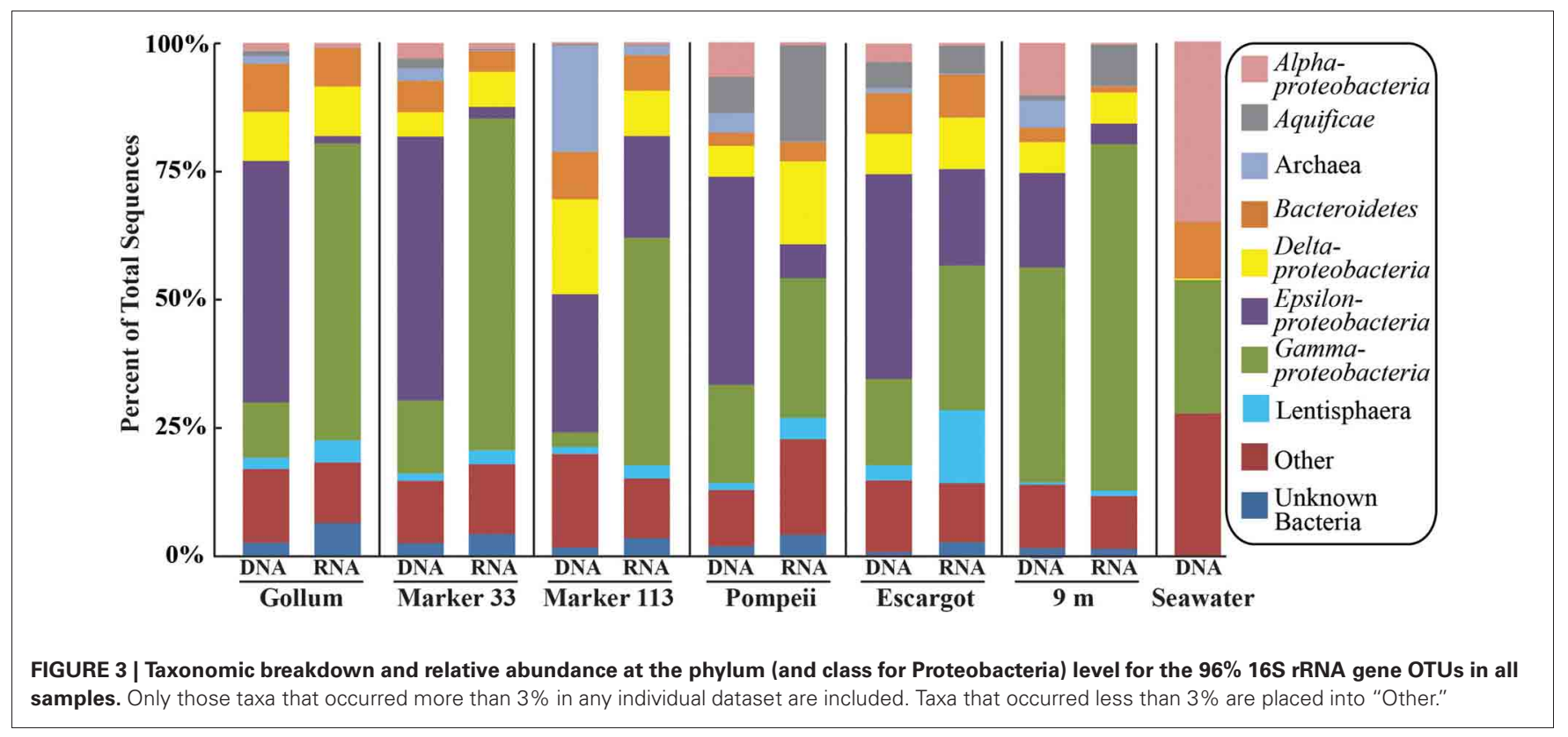

Environmental matching (Clarke and Gorley, 2006)] was used to match multivariate patterns of OTUs to chemical variables measured in the vent fluids (Table 1). For both all OTUs and only Epsilonproteobacterial OTUs, the most significant $\mathrm{R}$ value was with $\mathrm{CH}_{4} /$ Heat $(R=0.69, P$ value $=0.003$, Figure 6).

Gammaproteobacterial sequences were also treated separately due to their relatively high abundance in all RNA fractions (Figure 3). They were detected in all 12 hydrothermal vent fluid libraries, as well as background seawater. Within the Gammaproteobacteria, sequences belonging to the SUP05 clade were most frequently recovered, as well as those sequences related to animal endo- and ecto-symbionts (Figure 7, labeled "Unknown $\gamma \quad 2$ "). Principal coordinates analysis of all Gammaproteobacterial OTUs showed a clear distinction between DNA and RNA fractions (data not shown), similar to that seen for all OTUs. Gammaproteobacterial sequences were more abundant in RNA fractions than DNA fractions (Figure 7). Comparison of RNA and DNA profiles of the most abundant OTUs for Gammaproteobacteria shows high activity of Gammaproteobacteria in most vent fluids. Out of 67 Gammaproteobacteria OTUs considered, 56 were scored as active (Table 4).

\section{DISCUSSION}

Low-temperature diffuse vent samples represent combined hot hydrothermal vent fluid and deep seawater that mix and react 


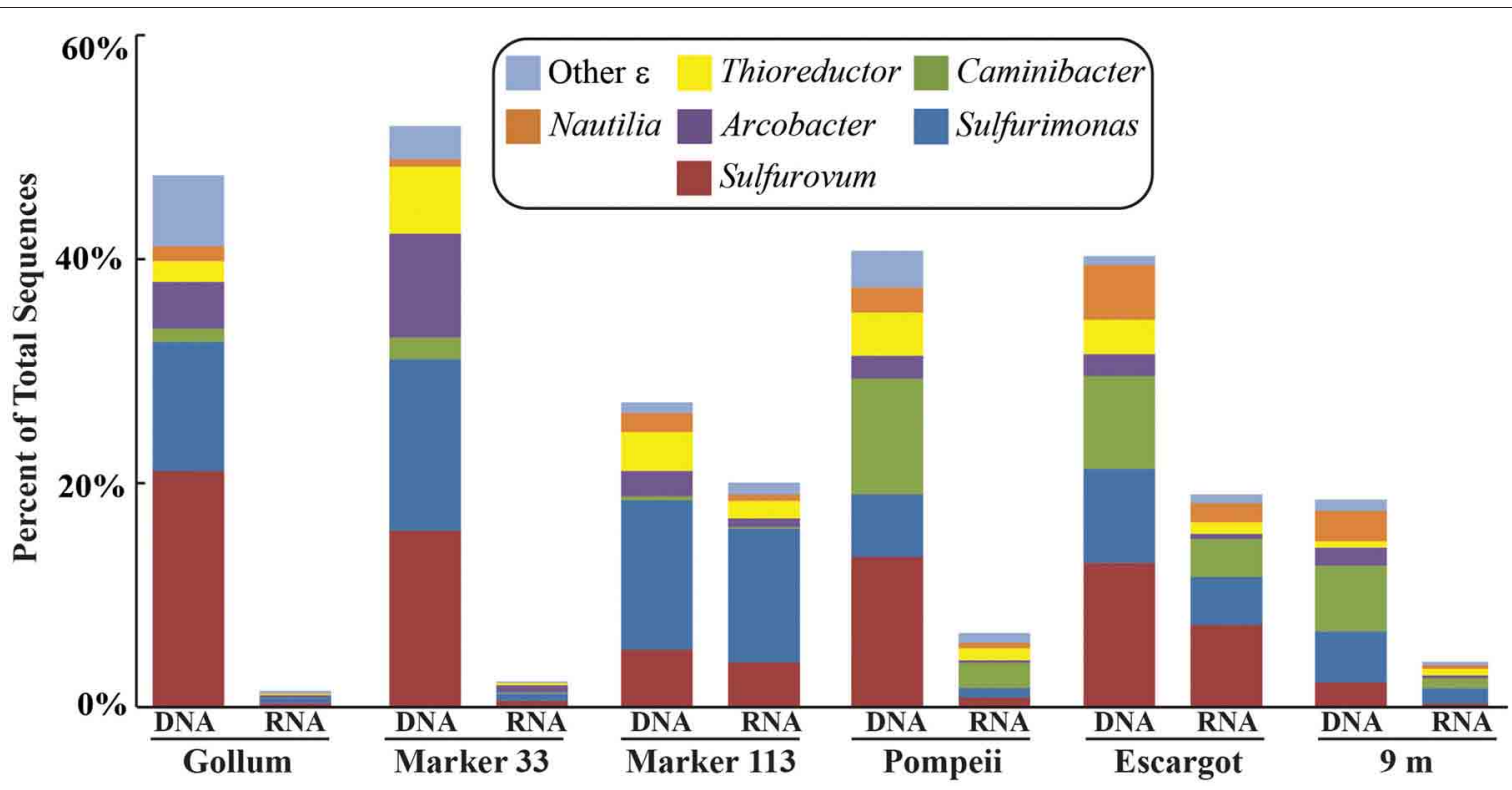

FIGURE 4 | Taxonomic breakdown and relative abundance of dominant Epsilonproteobacteria at the genus level for the $96 \% 16 S$ rRNA gene OTUs in each vent fluid sample. All other Epsilonproteobacterial sequences are placed into "Other."

Table 4 | Predicted percent activity based on 16S rRNA gene data.

\begin{tabular}{|c|c|c|c|c|c|c|}
\hline Site & \multicolumn{3}{|c|}{ Epsilonproteobacteria } & \multicolumn{3}{|c|}{ Gammaproteobacteria } \\
\hline Marker 33 & 79 & 0 & 0 & 39 & 35 & 89.7 \\
\hline Marker 113 & 41 & 17 & 41.5 & 13 & 13 & 100 \\
\hline Pompeii & 47 & 0 & 0 & 14 & 10 & 71.4 \\
\hline
\end{tabular}

a Number of OTUs that occur $>0.1 \%$ of all sequences in either RNA or DNA fraction.

${ }^{b}$ Number of OTUs that were scored as active if the RNA relative recovery was greater than its recovery from DNA.

beneath the seafloor. Mixing begins beneath the seafloor and continues as fluids vent and are diluted by ambient seawater as they rise up into the water column. By controlled pumping of fluids into a sampler intake that is inserted into the vents, the mixing that occurs with ambient seawater is controlled. However, even if dilution of the vent fluids with ambient seawater during sampling is not completely avoided, it is both possible and likely that seawater is entrained into the fluid along shallow mixing pathways in the subseafloor. Similarly, the microbial composition of the fluids reflects both seawater and subseafloor communities, which means that detection of vent-specific microbial processes can be challenging. By removing sequences from seawater organisms detected in background seawater from the vent fluid sample sequences, the analysis can focus on the diversity, distribution, and gene expression of vent-endemic subseafloor microbes. For this study, Epsilonproteobacteria that were not detected in background seawater were targeted to analyze their diversity, distribution, and sulfur-oxidizing gene patterns in the subseafloor.
The $\operatorname{sox} B$ gene primers were designed to screen for the hydrothermal vent sulfur-oxidizing Epsilonproteobacteria belonging to the genera Sulfurimonas, Sulfurovum, and Nitratiruptor. In particular, Sulfurimonas and Sulfurimonas are frequently detected at high abundances in diverse marine environments where strong gradients of oxygen and sulfide exist, including cold seep sediments (Roalkvam et al., 2011), waters of redoxclines (Grote et al., 2007), coastal marine sediments (Hoor, 1975), and both shallow and deep hydrothermal vents (Huber et al., 2010; Zhang et al., 2012). The primers do not detect Arcobacter, a genus within the Epsilonproteobacteria that also uses the Sox pathway. The 454 $16 \mathrm{~S}$ rRNA gene data in this study suggests Arcobacter are not dominant in most hydrothermal vent fluids at Axial Seamount, and while they are sometimes seen in high abundance (Huber et al., 2007), a single primer set to capture all Epsilonprotebacteria that use the Sox pathway was not possible to design due to the distant relationship in the $s o x B$ gene between the different genera (Meyer and Kuever, 2007; Headd and Engel, 2013). 


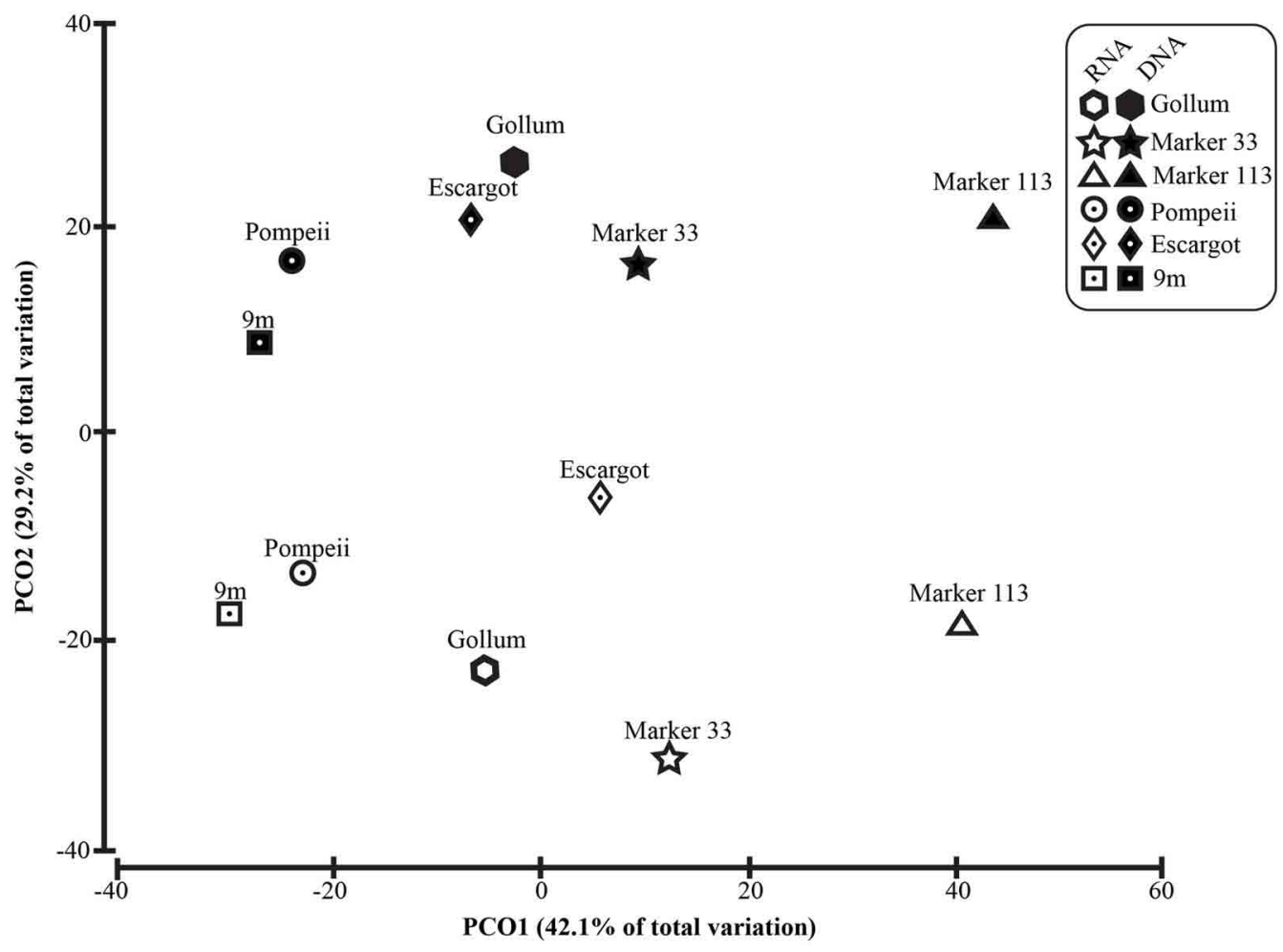

FIGURE 5 | Principal coordinates analysis of all 96\% 16S rRNA gene OTUs.

The soxB gene OTUs observed as Sulfurovum-like in this study generally shared the most identity with Sulfurovum sp. NBC371 , which was isolated from a deep-sea hydrothermal vent and is capable of both hydrogen and sulfur oxidation, as well as denitrification (Nakagawa et al., 2007; Yamamoto et al., 2010). Two other members of this genus have been isolated; one from a hydrothermal vent (S. lithotrophicum) and one from marine sediments (Candidatus S. sediminum). Both are also described as sulfur oxidizers, although neither has been shown to be capable of hydrogen utilization like NBC37-1 (Inagaki et al., 2004; Park et al., 2012). The soxB gene OTUs observed as Sulfurimonaslike in this study were closely related to cultivated species of Sulfurimonas. Sulfurimonas autotrophica was originally isolated from hydrothermal sediments (Inagaki et al., 2003), and other members of the genus have been identified associated with vent animals (Takai et al., 2006), in the redoxcline of the Baltic Sea (Grote et al., 2012), and in coastal marine sediments (Hoor, 1975; Sievert et al., 2008b). Genomic sequencing of some of these isolates shows multiple functional genes for different metabolic pathways such as sulfur oxidation, nitrate reduction, and hydrogen oxidation, highlighting their metabolic flexibility and similarity to members of the Sulfurovum (Sievert et al., 2008a; Grote et al., 2012). A key trait of all known isolates of both genera is that they cannot grow at $100 \%$ oxygen saturation; they are all described as facultative anaerobes (Inagaki et al., 2004; Takai et al., 2006). These two closely-related genera of Epsilonproteobacteria are likely occupying the same subseafloor habitat, but the $\operatorname{sox} B$ gene data suggests dominance of Sulfurimonas in active sulfur oxidation via the Sox pathway.

The $\operatorname{soxB}$ gene was not successfully amplified from either the DNA or RNA fraction of the Pompeii site. 16S rRNA profiles show Sulfurimonas and Sulfurovum are present at this site (Figure 4), and the geochemical conditions are within the range of growth of these organisms, therefore it is not clear why soxB did not amplify from these samples. In addition, the examination of Sulfurimonas and Sulfurovum 16S rRNA gene OTUs did not reveal any patterns specific to these populations at Pompeii and the reason for the lack of soxB detection at this site remains unknown.

At $9 \mathrm{~m}$, the $\operatorname{sox} B$ gene was not amplified from the RNA fraction, although soxB was detected in the DNA library. This is likely attributed to the high temperature (maximum $51.3^{\circ} \mathrm{C}$ ) of this metal-sulfide chimney site. Above $\sim 40^{\circ} \mathrm{C}$, sulfur oxidation is not favored due to severe oxygen limitation (McCollom and Shock, 1997; Butterfield et al., 2004), and known growth optima of all known cultures within Sulfurimonas and Sulfurovum are below $40^{\circ} \mathrm{C}$ (Inagaki et al., 2004; Takai et al., 2006). This site also had the lowest $\mathrm{pH}$ (4.8), which is still within the range of growth for Sulfurovum lithotrophicum (Inagaki et al., 2004), but outside of the range of growth for Sulfurimonas paralvinellae (Takai et al., 2006). A combination of low $\mathrm{pH}$ and high temperature likely contributes to the lack of $\operatorname{soxB}$ gene transcripts detected at this site.

At Gollum, the $\operatorname{sox} B$ genes and gene transcripts from the DNA and RNA fractions had very different signatures, with diverse 


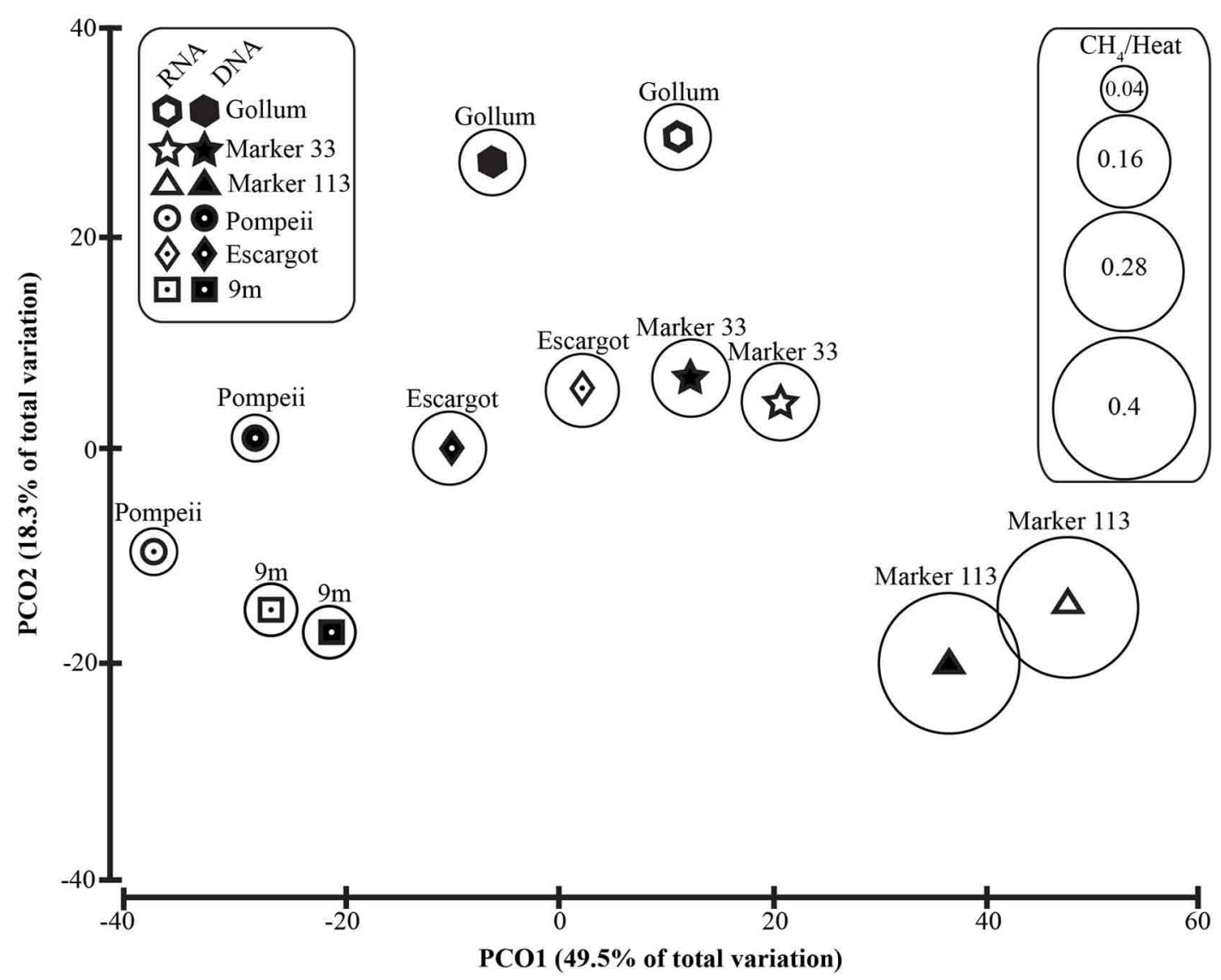

FIGURE 6 | Principal coordinates analysis of all 96\% Epsilonproteobacterial 16S rRNA gene OTUs with $\mathrm{CH}_{4} / \mathrm{Heat}$ ratios shown in bubbles surrounding symbols.

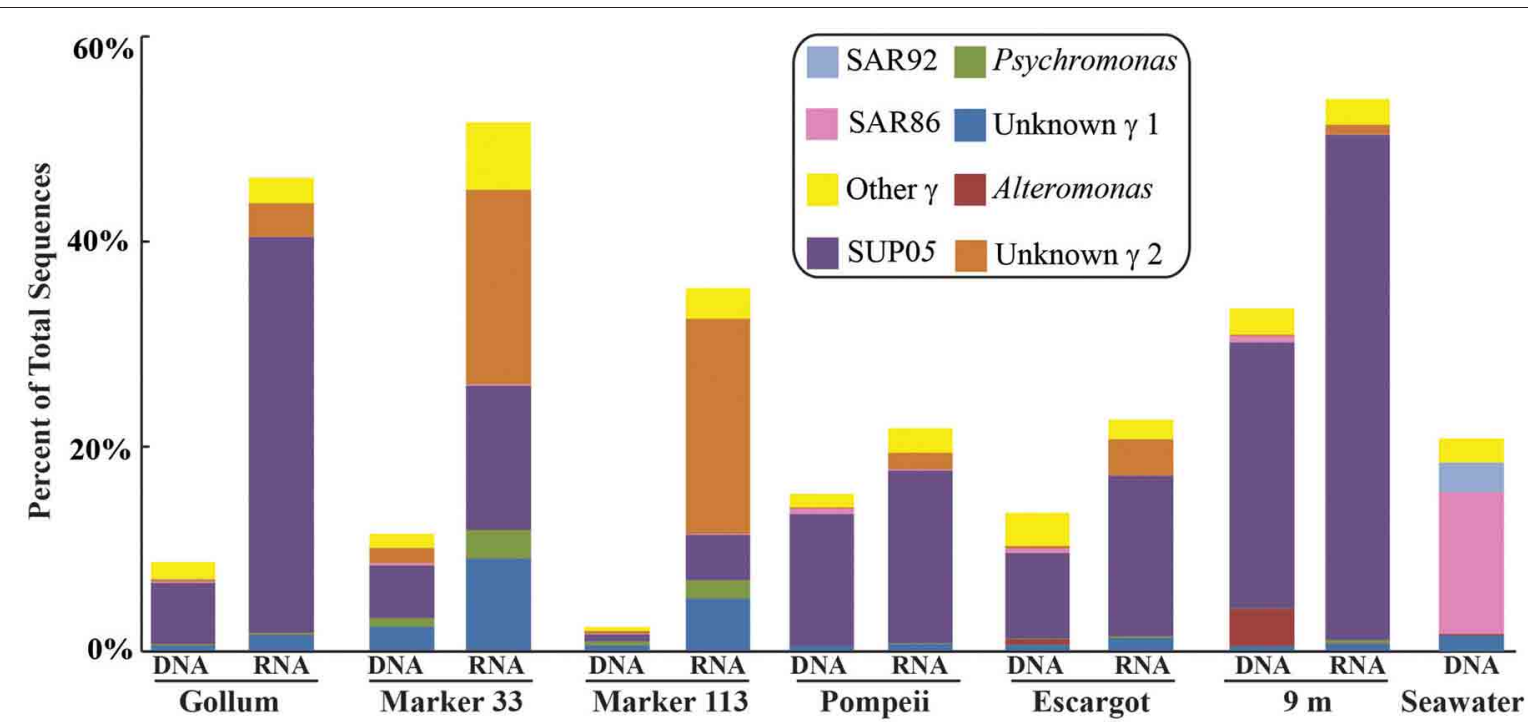

FIGURE 7 | Taxonomic breakdown and relative abundance of dominant Gammaproteobacteria at the genus level for $96 \% 16 \mathrm{~S}$ rRNA gene OTUs in each sample. All other Gammaproteobacteria sequences are lumped into "Other." 
Sulfurovum-like OTUs dominating the DNA fraction and a single Sulfurimonas-like OTU comprising almost the entire RNA fraction. In fact, the RNA profiles of $s o x B$ gene transcripts were nearly identical among the four vent fluid samples where soxB amplified and suggest that Sulfurimonas-like species are out-competing Sulfurovum in actively oxidizing sulfur via the Sox pathway in the subseafloor beneath each vent (Figure 2). Significant correlation between sulfide and proportions of Sulfurovum has previously been seen in diffuse fluids based on 16S rRNA gene sequencing (Perner et al., 2013), but here there were no statistically significant correlations in this genus with chemistry from either the $45416 \mathrm{~S}$ rRNA or $\operatorname{sox} B$ gene data. However, Gollum has the lowest concentration of hydrogen sulfide $(84 \mu \mathrm{M}$, Table 1), as well as the lowest $\mathrm{H}_{2} \mathrm{~S} /$ Heat ratio, suggesting low sulfide levels may favor the presence of Sulfurovum carrying the soxB gene. But given that all RNA profiles are dominated by Slms-1, there does not appear to be any correlation with respect to expression of $\operatorname{sox} B$ genes and sulfide to heat ratios or any other chemical variables.

Unlike recent work in terrestrial springs on sulfur oxidation genes (Headd and Engel, 2013), there is no evidence of niche partitioning in the active communities of Epsilonproteobacteria expressing the soxB gene. However, when examining all of the Epsilonproteobacteria 16S rRNA gene sequences (Figure 6), there was significant groupings related to the individual vent sampled and the type of vent (basalt or sulfide), highlighting the importance of physical isolation in helping to maintain stable microbial communities in the subseafloor (Huber et al., 2006, 2010; Opatkiewicz et al., 2009). There were also significant groupings of samples that correlated with chemical variables. The most significant correlation was with methane. Those vents high in methane are often conversely low in hydrogen (Figure 6, Table 1), suggesting hydrogen is being drawn down and methane generated by hydrogen-utilizing methanogens (Butterfield et al., 2004; Ver Eecke et al., 2012). At Marker 113, where the highest methane concentrations were seen, methanogenic archaea belonging to the genera Methanocaldococcus, Methanococcus, and Methanothermococcus were detected with the universal bacterial primer set, consistent with previous work at Marker 113 that showed hydrogenotrophic methanogens are abundant and active at this site (Ver Eecke et al., 2012).

There are no known Epsilonproteobacteria that use or generate methane, but many use hydrogen as an electron donor, including Caminibacter and Nautilia within the Nautiliaceae (Campbell et al., 2006). A higher relative abundance of tag sequences corresponding to these two genera were detected at Pompeii, Escargot, and $9 \mathrm{~m}$, and these samples were all collected from the sides of sulfide chimneys that had among the highest hydrogen concentrations (Table 1, Figure 4), suggesting the combination of geological structure and chemistry may favor these thermophilic, hydrogen-utilizing, sulfur-reducing Epsilonproteobacteria. This probably reflects the different niches these organisms occupy. Sulfurimonas and Sulfurovum are likely living in the more shallow, cool subseafloor where microaerobic niches exist, whereas members of the Nautiliaceae are likely residing further beneath the seafloor or in walls of sulfide chimneys in warm, anaerobic niches with enriched hydrogen. However, despite the overall structuring of the Epsilonproteobacterial microbial community revealed by $16 \mathrm{~S}$ rRNA gene sequencing, no patterns of the functional $\operatorname{sox} B$ gene were seen, suggesting that different lineages at each vent may be carrying out similar metabolic functions.

In addition to examining community patterns and gene expression of subseafloor Epsilonproteobacteria, the side-by-side comparison of $16 \mathrm{~S}$ rRNA gene patterns from DNA and RNA revealed that Gammaproteobacteria were present and active at all Axial Seamount vent sites (Table 4). The most abundant and active OTU belonged to the SUP05 clade, a ubiquitous group of bacteria frequently found in symbiotic association with hydrothermal vent animals (Newton et al., 2007) as well as in hydrothermal plumes, non-plume deep-sea water (Sunamura et al., 2004; Anantharaman et al., 2013; Dick et al., 2013), and oxygen minimum zones (Lavik et al., 2009; Walsh et al., 2009). Recent quantitative PCR data in low-temperature diffuse vents from Axial Seamount and Endeavour Segment also indicates SUP05 constitute up to $38 \%$ of all bacteria in some vent fluids (Bourbonnais et al., 2012; Anderson et al., 2013). There are no SUP05 from the deep sea in culture, but metagenomic and metatranscriptomic datasets indicate they are obligate autotrophs capable of sulfur and hydrogen oxidation, nitrate reduction, as well as storage of sulfur in globules (Walsh et al., 2009; Wright et al., 2012; Anantharaman et al., 2013). Active transcripts of multiple sulfur oxidation genes have even been detected in background seawater (Anantharaman et al., 2013), and while one metagenomic study suggests they are facultative anaerobes or strict anaerobes (Walsh et al., 2009), another suggests they can use oxygen in both fully aerobic and microaerobic conditions (Anantharaman et al., 2013).

There were a small number of sequences belonging to the SUP05 clade in the background seawater sample, and they were highly enriched in vent fluid samples, particularly the RNA fractions. However, when the Gammaproteobacterial 16S rRNA gene OTUs were analyzed, there were similar patterns to those seen when all OTUs were considered (Figure 5). This suggests that SUP05 are not vent-endemic or living in the subseafloor, but instead originate from background seawater and are enriched where the oxygen-rich deep seawater mixes with hydrogen sulfide-rich vent fluids in the very shallow subseafloor or as they exit the seafloor at the point of sampling. In contrast, the Epsilonproteobacteria sampled are being entrained into vent fluids from beneath the seafloor, where microaerobic and anaerobic pockets exist. Because the samples are being fixed immediately after filtration, those organisms active closer to the point of sampling will be over-represented in the RNA fraction. Organisms abundant within the seafloor will also be captured, but their activity will likely not be as representative of their in situ activity, given the unknown length of time for fluids and their resident microbes to travel from their particular subseafloor niche to the seafloor.

Many challenges remain in elucidating the subseafloor microbial ecosystem, but the coupled phylogenetic and functional gene analysis of DNA and RNA from low temperature diffuse vent fluids allows for a fuller picture of what may be occurring both at and within the seafloor at deep-sea hydrothermal vents. The detection of $\operatorname{soxB}$ gene transcripts shows there are active sulfur-oxidizing Epsilonproteobacteria within the subseafloor at Axial Seamount, 
mostly belonging to the genus Sulfurimonas. The 16S rRNA data suggests SUP05 are extremely active in the shallow subseafloor or at the seafloor where fluids are exiting from the crust and mixing with background seawater, the likely habitat of these organisms. Within the seafloor, it is predicted that Epsilonproteobacteria are the main sulfur oxidizers, given their ability to tolerate very low oxygen concentrations and use sulfur compounds as both electron acceptors and donors (Inagaki et al., 2004; Yamamoto and Takai, 2011). These results are consistent with previous work by Yamamoto and Takai (2011) and Anderson et al. (2013) suggesting that Gammaproteobacteria dominate when both oxygen and reduced sulfur compounds are steadily supplied but once oxygen begins to disappear, Epsilonproteobacteria have greater physiological and metabolic flexibility and potential to occupy diverse vent niches, especially in the subseafloor. Targeted functional approaches that focus on activity and expression of particular metabolic pathways, such as the primers developed here

\section{REFERENCES}

Amend, J. P., McCollom, T. M., Hentscher, M., and Bach, W. (2011). Catabolic and anabolic energy for chemolithoautotrophs in deep-sea hydrothermal systems hosted in different rock types. Geochim. Cosmochim. Acta 75, 5736-5748. doi: 10.1016/j.gca.2011.07.041

Anantharaman, K., Breier, J. A., Sheik, C. S., and Dick, G. J. (2013). Evidence for hydrogen oxidation and metabolic plasticity in widespread deep-sea sulfuroxidizing bacteria. Proc. Natl. Acad. Sci. U.S.A. 110, 330-335. doi: 10.1073/pnas. 1215340110

Anderson, R. E., Beltrán, M. T. Hallam, S. J., and Baross, J. A. (2013). Microbial community structure across fluid gradients in the Juan de Fuca Ridge hydrothermal system. FEMS Microbiol. Ecol. 83, 324-339. doi: 10.1111/j.1574-6941.2012.01478.x

Bonch-Osmolovskaya, E. A., Perevalova, A. A., Kolganova, T. V, Rusanov, I. I., Jeanthon, C., and Pimenov, N. V (2011). Activity and distribution of thermophilic prokaryotes in hydrothermal fluid, sulfidic structures, and sheaths of Alvinellids (East Pacific Rise, 13N). Appl. Environ. Microbiol. 77, 2803-2806. doi: 10.1128/AEM.02266-10

Bourbonnais, A., Juniper, S. K., Butterfield, D. A., Devol, A. H., Kuypers, M. M. M., Lavik, G., et al. (2012). Activity and abundance of denitrifying bacteria in the subsurface biosphere of diffuse hydrothermal vents of the Juan de Fuca Ridge. Biogeosciences 9, 4661-4678. doi: $10.5194 /$ bg-9-4661-2012
Boyce, R., Chilana, P., and Rose, T. M. (2009). iCODEHOP: a new interactive program for designing COnsensus-DEgenerate hybrid oligonucleotide primers from multiply aligned protein sequences. Nucleic Acids Res. 37, W222-W228. doi: 10.1093/nar/gkp379

Butterfield, D. A., Roe, K. K., Lilley, M. D., Huber, J. A., Baross, J. A., Embley, R. W., et al. (2004). "Mixing, reaction, and microbial activity in the sub-seafloor revealed by temporal and spatial variation in diffuse flow vents at Axial Volcano," in The Subseafloor Biosphere at MidOcean Ridges, eds W. S. D. Wilcock, E. F. DeLong, D. S. Kelley, J. A. Baross, and S. C. Cary (Washington, DC: American Geophysical Union), 269-289. doi: 10.1029/144GM17

Campbell, B. J., Engel, A. S., Porter, M. L., and Takai, K. (2006). The versatile $\varepsilon$-proteobacteria: key players in sulphidic habitats. Nat. Rev. Microbiol. 4, 458-468. doi: 10.1038/nrmicro1414

Clarke, K. R., and Gorley, R. N. (2006). PRIMER v6: user manual/tutorial. PRIMER-E.

Cowen, J. P., Copson, D. A., Jolly, J., Hsieh, C.-C., Lin, H.-T. T., Glazer, B. T., et al. (2012). Advanced instrument system for real-time and timeseries microbial geochemical sampling of the deep (basaltic) crustal biosphere. Deep Sea Res. I 61, 43-56. doi: 10.1016/j.dsr.2011.11.004

Dick, G. J., Anantharaman, K., Baker, B. J., Li, M., Reed, D. C., and Sheik, C. S. (2013). Hydrothermal vent plume microbiology: ecologi$\mathrm{cal}$ and biogeographic linkages to seafloor and water column habitats. Front. Microbiol. 4:124. doi: 10.3389/fmicb.2013.00124

combined with incubation experiments or in situ studies, will help elucidate how these organisms differentiate into their respective niches and contribute to the biogeochemical cycling of sulfur and carbon both in the deep sea and subseafloor.

\section{ACKNOWLEDGMENTS}

We thank the crews of the R/V Thomas G. Thompson and ROV Jason II for their assistance with fieldwork, and Kevin K. Roe, Hoang-My Christensen, Marvin Lilley, and Eric Olson for chemical analyses. This work was supported by a NASA Astrobiology Postdoctoral Program Fellowship to Nancy H. Akerman and grants from the NSF Division of Ocean Sciences to Julie A. Huber (OCE-0929167) and David A. Butterfield (OCE-0731947 and OCE-0926199), and by the Joint Institute for the Study of the Atmosphere and Ocean (JISAO contribution \#2073, PMEL contribution \#3984) under NOAA Cooperative Agreement No. NA17RJ1232.

Edgar, R. C. (2010). Search and clustering orders of magnitude faster than BLAST. Bioinformatics 26, 2460-2461. doi: 10.1093/ bioinformatics/btq461

Embley, R. W., Murphy, K. M., and Fox, C. G. (1990). High-resolution studies of the summit of Axia Volcano. J. Geophys. Res. 95, 12785-12812. doi: 10.1029/JB095 iB08p 12785

Felsenstein, J. (1989). PHYLIP Phylogeny inference package. Cladistics 5, 164-166.

Filkins, L. M., Hampton, T. H., Gifford, A. H., Gross, M. J., Hogan, D. A., Sogin, M. L., et al. (2012). The prevalence of Streptococci and increased polymicrobial diversity associated with cystic fibrosis patient stability. J. Bacteriol. 194, 4709-4717. doi 10.1128/JB.00566-12

Fredslund, J., Schauser, L., Madsen, L. H., Sandal, N., and Stougaard, J. (2005). PriFi: using a multiple alignment of related sequences to find primers for amplification of homologs. Nucleic Acids Res. 33, W516-W520. doi 10.1093/nar/gki425

Friedrich, C. G., Bardischewsky, F., Rother, D., Quentmeier, A., and Fischer, J. (2005). Prokaryotic sulfur oxidation. Curr. Opin. Microbiol. 8, 253-259. doi: 10.1016/j.mib.2005.04.005

Friedrich, C. G., Rother, D. Quentmeier, A., Fischer, J. and Bardischewsky, F. (2001) Oxidation of reduced inorganic sulfur compounds by bacteria: emergence of a common mechanism? Appl. Environ. Microbiol. 67, 2873-2880. doi 10.1128/AEM.67.7.2873-2882.2001
Gadberry, M. D., Malcomber, S. T., Doust, A. N., and Kellogg, E. A. (2005). Primaclade-a flexible tool to find conserved PCR primers across multiple species. Bioinformatics 21, 1263-1264. doi: 10.1093/bioinformatics/btil34

Grote, J., Labrenz, M., Pfeiffer, B., Jost, G., and Jurgens, K. (2007). Quantitative distributions of Epsilonproteobacteria and a Sulfurimonas subgroup in pelagic redoxclines of the Central Baltic Sea. Appl. Environ. Microbiol. 73, 7155-7161. doi: 10.1128/AEM.00466-07

Grote, J., Schott, T., Bruckner, C. G., Oliver, F., Jost, G., and Teeling, H. (2012). Genome and physiology of a model Epsilonproteobacterium responsible for sulfide detoxification in marine oxygen depletion zones. Proc. Natl. Acad. Sci.U.S.A. 109, 506-510. doi: 10.1073/pnas.1111262109

Headd, B., and Engel, A. S. (2013). Evidence for niche partitioning revealed by the distribution of sulfur oxidation genes collected from areas of a terrestrial sulfidic spring with differing geochemical conditions. Appl. Environ. Microbiol. 79, 1171-1182. doi: 10.1128/AEM.02812-12

Hoor, A. T.-T. (1975). A new type of thiosulphate oxidizing, nitrate reducing microorganism: Thiomicrospira denitrificans sp. Nov. Neth. J. Sea Res. 9, 344-346. doi: 10.1016/0077-7579(75)90008-3

Horn, H. S. (1966). Measurement of "overlap" in comparative ecological studies. Am. Nat. 100, 419-424. doi $10.1086 / 282436$

Huber, J. A., Butterfield, D. A., and Baross, J. A. (2002). Temporal 
changes in archaeal diversity and chemistry in a mid-ocean ridge subseafloor habitat. Appl. Environ. Microbiol. 68, 1585-1594. doi: 10.1128/AEM.68.4.1585-1594.2002

Huber, J. A., Butterfield, D. A., and Baross, J. A. (2003). Bacterial diversity in a subseafloor habitat following a deep-sea volcanic eruption. FEMS Microbiol. Ecol. 43, 393-409. doi: 10.1111/j.15746941.2003.tb01080.x

Huber, J. A., Butterfield, D. A., and Baross, J. A. (2006). Diversity and distribution of subseafloor Thermococcales populations in diffuse hydrothermal vents at an active deep-sea volcano in the northeast Pacific Ocean. J. Geophys. Res. 111, 1-13. doi: 10.1029/2005JG000097

Huber, J. A., Morrison, H. G., Huse, S. M., Neal, P. R, Sogin, M. L., and Mark Welch, D. B. (2009). Effect of PCR amplicon size on assessments of clone library microbial diversity and community structure. Environ. Microbiol. 11, 1292-1302. doi: 10.1111/j.1462-2920.2008.01857.x

Huber, J. A., Cantin, H. V., Huse, S. M., Welch, D. B. M., Sogin, M. L., Butterfield, D. A., et al. (2010). Isolated communities of Epsilonproteobacteria in hydrothermal vent fluids of the Mariana Arc seamounts. FEMS Microbiol. Ecol. $73,538-549$.

Huber, J. A., Mark Welch, D. B., Morrison, H. G., Huse, S. M., Neal, P. R., Butterfield, D. A., et al. (2007). Microbial population structures in the deep marine biosphere. Science 318, 97-100. doi: 10.1126/science.1146689

Hügler, M., Gärtner, A., Imhoff, F. J., and Imhoff, J. F. (2010). Functional genes as markers for sulfur cycling and $\mathrm{CO} 2$ fixation in microbial communities of hydrothermal vents of the Logatchev field. FEMS Microbiol. Ecol. 73, 526-537.

Huse, S. M., Dethlefsen, L., Huber, J. A., Welch, D. M., Relman, D. A., and Sogin, M. L. (2008). Exploring microbial diversity and taxonomy using SSU rRNA hypervariable tag sequencing. PLoS Genet. 4:e1000255. doi: 10.1371/journal.pgen.1000255

Inagaki, F., Takai, K., Kobayashi, H., Nealson, K. H., and Horikoshi, K. (2003). Sulfurimonas autotrophica gen. nov., sp. nov., a novel sulfuroxidizing epsilon-proteobacterium isolated from hydrothermal sediments in the Mid-Okinawa Trough. Int. J. Syst. Evol. Microbiol. 53, 1801-1805. doi: 10.1099/ijs.0.02682-0
Inagaki, F., Takai, K., Nealson, K. H., and Horikoshi, K. (2004). Sulfurovum lithotrophicum gen. nov., sp. nov., a novel sulfuroxidizing chemolithoautotroph within the e-Protoebacteria isolated from Okinawa Trough hydrothermal sediments. Int. J. Syst. Evol. Microbiol. 54, 1477-1482. doi: 10.1099/ijs.0.03042-0

Jannasch, H. W., and Mottl, M. J. (1985). Geomicrobiology of deep-sea hydrothermal vents. Science 229, 717-725. doi: 10.1126/science.229.4715.717

Jones, S. E., and Lennon, J. T. (2010). Dormancy contributes to the maintenance of microbial diversity. Proc. Natl. Acad. Sci. U.S.A. 107, 5881-5886. doi: 10.1073/pnas.0912765107

Kappler, U., and Dahl, C. (2001). Enzymology and molecular biology of prokaryotic sulfite oxidation. FEMS Microbiol. Lett. 203, 1-9.

Lavik, G., Stuhrmann, T., Bruchert, V., Van der Plas, A., Mohrholz, V., Lam, P., et al. (2009). Detoxification of sulphidic African shelf waters by blooming chemolithotrophs. Nature 457, 581-585. doi: 10.1038/nature 07588

McCollom, T. M., and Shock, E. L. (1997). Geochemical constraints on chemolithoautotrophic metabolism by microorganisms in seafloor hydrothermal systems. Geochim. Cosmochim. Acta 61, 4375-4391. doi: 10.1016/S00167037(97)00241-X

Meyer, B., and Kuever, J. (2007). Molecular analysis of the diversity of sulfate-reducing and sulfuroxidizing prokaryotes in the environment, using aprA as functional marker gene. Appl. Environ. Microbiol. 73, 7664-7679. doi: 10.1128/AEM.01272-07

Meyer, B., Imhoff, J. F., and Kuever, J. (2007). Molecular analysis of the distribution and phylogeny of the soxB gene among sulfur-oxidizing bacteria-evolution of the Sox sulfur oxidation enzyme system. Environ. Microbiol. 9, 2957-2977. doi: 10.1111/j.1462-2920.2007.01407.x

Meyer, J. L., Akerman, N. H., Proskurowski, G., and Huber, J. A. (2013). Microbiological characterization of post-eruption "snowblower" vents at Axial Seamount, Juan de Fuca Ridge. Front. Microbiol. 4:153. doi: 10.3389/fmicb.2013.00153

Nakagawa, S., and Takai, K. (2008). Deep-sea vent chemoautotrophs: diversity, biochemistry and ecological significance. FEMS Microbiol.
Ecol. 65, 1-14. doi: 10.1111/j.15746941.2008.00502.x

Nakagawa, S., Takaki, Y., Shimamura, S., Reysenbach, A., and Takai, K. (2007). Deep-sea vent epsilonproteobacterial genomes provide insights into mergence of pathogens. Proc. Natl. Acad. Sci. U.S.A. 104, 12,146-12,150. doi: 10.1073/pnas.0700687104

Newton, I. L. G., Woyke, T., Auchtung, T. A., Dilly, G. F., Dutton, R. J., Fisher, M. C., et al. (2007). The Calyptogena magnifica chemoautotrophic symbiont genome. Science 315, 998-1000. doi: 10.1126/science.1138438

Opatkiewicz, A. D., Butterfield, D. A., and Baross, J. A. (2009). Individual hydrothermal vents at Axial Seamount harbor distinct subseafloor microbial communities. FEMS Microbiol. Ecol. 70, 413-424. doi: 10.1111/j.1574-6941.2009.00747.x

Orcutt, B. N., Sylvan, J. B., Knab, N. J., and Edwards, K. J. (2011). Microbial ecology of the dark ocean above, at, and below the seafloor. Microbiol. Mole. Biol. Rev. 75, 361-422. doi: 10.1128/MMBR.00039-10

Park, S.-J., Ghai, R., Martin-Cuadrado, A.-B., Rodriguez-Valera, F., Jung, M.-Y., Kim, J.-G., et al. (2012). Draft genome sequence of the sulfur-oxidizing bacterium "Candidatus Sulfurovum sediminum" AR, which belongs to the Epsilonproteobacteria. J. Bacteriol. 194, 4128-4129. doi: 10.1128/JB.00741-12

Perner, M., Gonnella, G., Hourdez, S., Böhnke, S., Kurtz, S., and Girguis, P. (2013). In situ chemistry and microbial community compositions in five deep-sea hydrothermal fluid samples from Irina II in the Logatchev field. Environ. Microbiol. 15, 1551-1560. doi: 10.1111/1462-2920.12038

Petri, R., Lilijana, P., and Johannes, F. I. (2001). Phylogeny and distribution of the sox $\mathrm{B}$ gene among thiosulfate-oxidizing bacteria. FEMS Microbiol. Lett. 197, 171-178. doi: 10.1111/j.15746968.2001.tb10600.x

Rice, P., Longden, I., and Bleasby, A. (2000). EMBOSS: the European molecular biology open software suite. Trends Genet. 16, 276-277. doi: 10.1016/\$0168-9525 (00)02024-2

Roalkvam, I., Jørgensen, S. L., Chen, Y., Stokke, R., Dahle, H., Hocking, W. P., et al. (2011). New insight into stratification of anaerobic methanotrophs in cold seep sediments. FEMS
Microbiol. Ecol. 78, 233-243. doi: 10.1111/j.1574-6941.2011.01153.x

Rose, T. (2003). CODEHOP (COnsensus-DEgenerate hybrid oligonucleotide primer) PCR primer design. Nucleic Acids Res. 31, 3763-3766. doi: 10.1093/ nar/gkg524

Schloss, P. D., Westcott, S. L., Ryabin, T., Hall, J. R., Hartmann, M., Hollister, E. B., et al. (2009). Introducing mothur: opensource, platform-independent, community-supported software for describing and comparing microbial communities. Appl. Environ. Microbiol. 75, 7537-7541. doi: 10.1128/AEM.01541-09

Sievert, S. M., Hugler, M., Taylor, C. D., and Wirsen, C. O. (2008a). "Sulfur oxidation at deep-sea hydrothermal vents," in Microbial Sulfur Metabolism, eds C. Dahl and C. G. Friedrich (New York, NY: Springer), 238-258. doi: 10.1007/978-3-540-72682-1_19

Sievert, S. M., Scott, K. M., Klotz, M. G., Chain, P. S. G., Hauser, L. J., Hemp, J., et al. (2008b). Genome of the epsilonproteobacterial chemolithoautotroph Sulfurimonas denitrificans. Appl. Environ. Microbiol. 74, 1145-1156. doi: 10.1128/AEM.01844-07

Sikorski, J., Christine, M., Alla, L., Olivier Ngatchou, D., Susan, L., Tijana Glavina Del, R., et al. (2010). Complete genome sequence of Sulfurimonas autotrophica type strain (OK10T). Stand. Genom. Sci. 3, 194-202.

Sogin, M. L., Morrison, H. G., Huber, J. A., Mark Welch, D., Huse, S. M., Neal, P. R., et al. (2006). Microbial diversity in the deep sea and the underexplored "rare biosphere". Proc. Natl. Acad. Sci. U.S.A. 103, 12115-12120. doi: 10.1073/pnas.0605127103

Sunamura, M., Higashi, Y., Miyako, C., Ishibashi, J., and Maruyama, A. (2004). Two bacteria phylotypes are predominant in the Suiyo Seamount hydrothermal plume. Appl. Environ. Microbiol. 70, 1190-1198. doi: 10.1128/AEM.70.2.1190-1198.2004

Swan, B. K., Martinez-Garcia, M., Preston, C. M., Sczyrba, A., Woyke, T., Lamy, D., et al. (2011). Potential for chemolithoautotrophy among ubiquitous bacteria lineages in the dark ocean. Science 333, 1296-1300. doi: 10.1126/science. 1203690

Takai, K., Suzuki, M., Nakagawa, S., Miyazaki, M., Suzuki, Y., Inagaki, F., et al. (2006). Sulfurimonas paralvinellae sp. nov., a novel mesophilic, 
hydrogen- and sulfur-oxidizing chemolithoautotroph within the Epsilonproteobacteria isolated from a deep-sea hydrothermal vent polychaete nest, reclassification of Thiomicrospira denitrificans as Sulfurimonas denitrificans comb. nov. and emended description of the genus Sulfurimonas. Int. J. Syst. Evol. Microbiol. 56, 1725-1733. doi: 10.1099/ijs.0.64255-0

Tamura, K., Dudley, J., Nei, M., and Kumar, S. (2007). MEGA4: molecular evolutionary genetics analysis (MEGA) software version 4.0. Mole. Biol. Evol. 24, 1596-1599. doi: 10.1093/molbev/ msm092

Ver Eecke, H. C., Butterfield, D. A., Huber, J. A., Lilley, M. D., Olson, E. J., Roe, K. K., et al. (2012). Hydrogen-limited growth of hyperthermophilic methanogens at deep-sea hydrothermal vents. Proc. Natl. Acad. Sci.U.S.A. 109, 13674-13679. doi: 10.1073/pnas.1206632109

Walsh, D. A., Zaikova, E., Howes, C. G., Song, Y. C., Wright, J. J., Tringe, S. G., et al. (2009). Metagenome of a versatile chemolithoautotroph from expanding oceanic dead zones. Science 326, 578-582. doi: 10.1126/science.1175309

Wright, J. J., Konwar, K. M., and Hallam, S. J. (2012). Microbial ecology of expanding oxygen minimum zones. Nat. Rev. Microbiol. 10, 381-394.

Yamamoto, M., Satoshi, N., Shigeru, S., Takai, K., and Horikoshi, K. (2010). Molecular characterization of inorganic sulfur-compound metabolism in the deepsea epsilonproteobacterium Sulfurovum sp. NBC37-1. Environ.
Microbiol. 12, 1144-1153. doi: 10.1111/j.1462-2920.2010.02155.x

Yamamoto, M., and Takai, K. (2011). Sulfur metabolisms in epsilonand gamma-proteobacteria in deep-sea hydrothermal fields. Front. Microbiol. 2:192. doi: 10.3389/fmicb.2011.00192

Zhang, Y., Zhao, Z., Chen, C.-T. A., Tang, K., Su, J., and Jiao, N. (2012). Sulfur metabolizing microbes dominate microbial communities in andesite-hosted shallow-sea hydrothermal systems. PLoS ONE 7:e44593. doi: 10.1371/journal.pone.0044593

Conflict of Interest Statement: The authors declare that the research was conducted in the absence of any commercial or financial relationships that could be construed as a potential conflict of interest.
Received: 16 February 2013; accepted: 18 June 2013; published online: 08 July 2013.

Citation: Akerman NH, Butterfield DA and Huber JA (2013) Phylogenetic diversity and functional gene patterns of sulfur-oxidizing subseafloor Epsilonproteobacteria in diffuse hydrothermal vent fluids. Front. Microbiol. 4:185. doi: 10.3389/fmicb. 2013.00185

This article was submitted to Frontiers in Extreme Microbiology, a specialty of Frontiers in Microbiology.

Copyright (c) 2013 Akerman, Butterfield and Huber. This is an open-access article distributed under the terms of the Creative Commons Attribution License, which permits use, distribution and reproduction in other forums, provided the original authors and source are credited and subject to any copyright notices concerning any third-party graphics etc. 